\title{
III - A Administração Internacional de Recursos Humanos
}

Obviamente, a dimensão internacional, adquirida pela administração em nossos dias, afeta, em maior ou menor escala, praticamente todas as suas áreas ou campos de atuação, ou seja, as suas chamadas especializações.

No que concerne à estrutura ou organização, por exemplo, assim se expressa Herbert Hicks :

"Um dos problemas dos negócios internacionais é a estruturação das relações organizacionais multinacionais. Tradicionalmente, têm as firmas estabelecido organizações centrais das quais conservam pleno controle sobre o planejamento estratégico e a tomada de decisões. Contudo, fatores tais como o isolamento da alta direção das operações de além-mar, a barreira lingüistica e complexas legislações governamentais próprias de cada lugar tornaram essa forma de organização um tanto obsoleta. Como alternativa, as empresas internacionais, não raro, são descentralizadas geograficamente, com superintendentes de área para várias localidades. Esses superintendentes dispõem, com freqüência, de grande autonomia em relação à matriz para gerir os seus negócios. Quando uma firma se acha assim descentralizada, cada divisão se encontra em melhor posição para responder à cultura em que opera" (18).

A influência do ambiente internacional sobre as comunicações é evidente e dispensa maior comentário ou demonstração. blicas.

O mesmo se pode dizer, sem hesitar, no que concerne às relações pú-

Ambos esses domínios - nos quais a utilização da linguagem, sob as suas mais variadas formas e modalidades, é fundamental e primordial - são, como é patente, fortemente afetados, para não mencionar outros fatores, pela tão enfatizada barreira lingüistica.

Daí Erik Linder falar de uma propaganda internacional como matéria especifica e caracterizada para ser estudada com especial atençăo, dando o seguinte exemplo para pôr bem em evidência a sua idéia :

Op. cit., p. 488 .

R. Serv. públ., Brasilia, 109 (4) out./dez. 1974 
"Que aconteceria se o gerente de propaganda da Coca-Cola, por exemplo, sugerisse à sua companhia 50 campanhas de propaganda diferentes no mercado americano, uma para cada Estado? Estaria ele ainda na folha de pagamento no mês seguinte?

"Se, por outro lado, propusesse 18 campanhas diferentes e 18 agências de propaganda diferentes para comercializar um produto na Europa Ocidental hoje, poderia ser indicado para uma promoção" (19).

A administração de material e, em particular, o sistema de compras, ao mudar de habitat, podem defrontar-se e, comumente, se defrontam, não só com a barreira lingüistica e práticas diferentes de comércio, como também com outros códigos de ética que, não raro, transformam em faltas e, até mesmo, em cr'mes, atos perfeitamente legítimos em outros ambientes.

Não é de admirar, assim, que A. A. Sherbini procure identificar um marketing internacional, com caracteristicas próprias e distintivas, a muitos respeitos, de seu correspondente de âmbito nacional (20).

E não é, outrossim, de causar surpresa que Gerhard G. Mueller, por sua $v \in z$, chegue a falar também de uma contabilidade internacional como disciplina a ser incluida nos currículos universitários (21).

Mas, evidentemente, de todos os campos ou áreas de especialização da administração, a mais afetada pela sua internacionalização é a dos recursos humanos.

Isso é perfeitamente natural e compreensivel.

O homem, em verdade, é o único ser vivo das organizações, revelandose todos os demais elementos - material, equipamento, dinheiro, estrutura, chefia, liderança etc. - coisas inanimadas ou abstratas, por ele manobradas, manuseadas ou manipuladas, em uma palavra, geridas ou administradas (22).

E, assim, óbvio que o elemento humano seja o que, por assim dizer, mais sofre com o transplante da administração do habitat nacional para o habitat internacional.

As diferenças ambientais com que ele se defronta na administração internacional são de quatro tipos principais : 1) físico ou espacial; 2) sócio-eco-

(19) Richard N. Farmer, Op. cit., p. 243. Veja-se, todavla, todo o capitulo sobre o assunto, pp. 243-252.

(20) Idem, ibidem, pp. 253-263.

(21) Idem, ibidem, pp. 227-241.

(22) A. Fonseca Pimentel, Alguns Aspectos do Treinamento, 2.' ed., Rlo de Janeiro, Fundação Getúlio Vargas, 1966, pp. 4-6.

R. Serv. públ., Brasilla, 109 (4) out./dez. 1974 
nömico; 3) sócio-cultural; 4) técnico, para não mencionar a maior ou menor distância geográfica que o separa do meio familiar e social em que está habituado a viver.

A capacidade de resistir a essa separação, por um período de tempo mais ou menos longo, é um teste em que muito funcionário, altamente qualificado do ponto de vista profissional, não tem passado, malogrando, por isso, na missão e retornando antecipadamente ao solo pátrio, não raro com prejuízos para a organização e para ele próprio.

O ambiente físico ou espacial põe, a miúde, o funcionário internacional em regiões de condições climáticas diametralmente opostas às de sua terra nativa, como, por exemplo, no caso de um brasileiro que vá servir nos países escandinavos ou vice-versa. Expõe-no também a freqüentes riscos de saúde, quando se trata de missão ou posto em locais remotos e destituídos das condições sanitárias desejáveis, como ocorre em diversos países da África, da Asia e da América Latina.

O ambiente sócio-econômico faz o funcionário internacional confrontarse, não raro, em países muito subdesenvolvidos, com o espetáculo de uma miséria generalizada, que confrange o coração e torna a sua permanência no lc:cal, às vezes, muito desagradável.

O ambiente sócio-cultural oferece, com freqüência, ao funcionário internacional, além da barreira lingüistica, costumes estranhos, que ele não entende e, de bom grado, não aceitaria, assim como também, muitas vezes, a indiferença ou mesmo hostilidade dos círculos locais. Isso, quando ocorre, tornalhe extremamente difícil o desempenho de sua missão, obrigando-o, outrossim, às vezes, a abandoná-la, se não possuir as qualidades necessárias para resistir a essa prova.

Finalmente, o ambiente técnico - que se relaciona diretamente com a sua função e as suas capacidades profissionais - pode revelar-se, não raro, completamente diferente daquele em que ele está acostumado a trabalhar, obrigando-o a tremendos esforços para dominar instrumentais que ele mal conhece, seja por se mostrarem mais sofisticados ou mais rudimentares do que aqueles com que ele está habituado a lidar.

rudo isso leva ao resultado de que a taxa de turnover ou de movimentação de pessoal na administração internacional costuma ser alta, de 15 a $20 \%$, segundo alguns especialistas (23).

A situação foi muito bem sintetizada por Endel J. Kolde com as seguintes palavras:

(23) Franlin R. Root e David A. Heenan, "Staffing in Overseas Unit" in Handbook of Modern Personnel Administration, Editor-in-Chlef, Joseph J. Famularo, New York, McGraw-Hill Book Company, 1972, Cap. 56, p. 4.

R. Serv. públ., Brasília, 109 (4) out./dez. 1974 
"A diferença fundamental entre os negócios internacionais e domésticos reside em suas molduras ambientais e nas reações organizacionais e comportamentais que fluem dessas molduras. Quando uma empresa extravasa de um meio nacional, a sua moldura ambiental muda progressivamente em inúmeros respeitos. Aparecem novas disposiçōes ou regulamentações estabelecidas pela lei, pelos costumes e pela cultura; novos valores éticos; novas contradições externas; e novas oportunidades, assim como novas incertezas. Quanto mais largo o âmbito de ação internacional da companhia, maiores serão as diversidades ambientais que a circundam" (24).

Disso resulta, no âmbito internacional, uma administração de recursos humanos com fisionomia própria e características bem marcadas, como se verá, pela análise de alguns de seus aspectos, no próximo capítulo.

(24) Citado por Fremont E. Kast e James E. Rosenzweig in Organization and Mana. gement: A Systems Approach, New York, McGraw-Hill Book Company, 1970. p. 591 .

R. Serv. públ., Brasília, 109 (4) out./dez, 1974 